Reviu Akuntansi dan Bisnis Indonesia, Vol. 1 No. 2, Hlm: 90-105, Desember 2017

Website: http://journal.umy.ac.id/index.php/rab

\title{
Pengaruh Mekanisme Corporate Governance dan Budaya Perusahaan Terhadap Corporate Risk Disclosures (Studi Komparatif pada Perusahaan Manufaktur yang Terdaftar di Bursa Efek Indonesia dan Bursa Malaysia Tahun 2016)
}

\begin{abstract}
Ajeng Kurniawati; Hafiez Sofyani
Program Studi Akuntansi Univeritas Muhammadiyah Yogyakarta.

A B S T R A K

Penelitian ini bertujuan menganalisis pengaruh tekanan waktu, independensi, skeptisisme profesional, dan pengalaman kerja terhadap kemampuan pendeteksian kecurangan laporan keuangan auditor. Subjek dalam penelitian ini yaitu auditor eksternal yang bekerja di Badan Pemeriksa Keuangan Republik Indonesia di Daerah Istimewa Provinsi Yogyakarta. Dalam penelitian ini, sampel 37 responden dipilih menggunakan purposive sampling. Empat puluh lima kuesioner diberikan kemudian tiga puluh tujuh kuesioner dikembalikan dan dapat diperiksa menggunakan model regresi linier berganda. Alat analisis yang digunakan dalam penelitian ini adalah SPSS 22. Berdasarkan analisis yang telah dilakukan hasilnya adalah tekanan waktu berpengaruh negatif terhadap kemampuan deteksi kecurangan auditor. Independensi, skeptisisme profesional, dan pengalaman kerja berpengaruh positif pada kemampuan deteksi kecurangan auditor.
\end{abstract}

(c) 2019 RAB. Published by Universitas Muhammadiyah Yogyakarta

\section{PENDAHULUAN}

Perkembangan perekonomian dalam lingkup akuntansi yang terkait dengan perusahaan besar dimana terdapat kasus yang telah terungkap dan dapat menyebabkan krisis keuangan. Kasus tersebut muncul dikarenakan kurang baiknya tata kelola yang dilakukan oleh perusahaan serta kurang diterapkannya transparansi pelaporan keuangan secara maksimal. Perusahaan dituntut untuk menerapkan transparansi dalam mengungkapkan beberapa informasi yang dapat digunakan oleh perusahaan keuangan maupun perusahaan non-keuangan yaitu termasuk informasi mengenai risiko perusahaan (Atika, 2016).

Sesuai dengan Surat Edaran Ketua Badan Pengawas Pasar Modal Nomor: SE- 02/PM/2002 tentang Pedoman Penyajian dan Pengungkapan Laporan Keuangan Emiten atau Perusahaan Publik dimana setiap perusahaan harus melakukan pengungkapan secara penuh. Pengungkapan yang dilakukan perusahaan dapat berupa pengungkapan wajib (mandatory disclosures) dan pengungkapan sukarela (voluntary disclosure).

Pengungkapan risiko merupakan pengungkapan sukarela namun dianggap penting sesuai dengan peraturan yang dikeluarkan oleh Ikatan Akuntan Indonesia (IAI) yang tercantum di dalam PSAK No 60. Dijelaskan bahwa untuk mengevaluasi tingkat dan jenis risiko dalam perusahaan dibutuhkan informasi yang berupa pengungkapan perusahaan keuangan yang terdiri atas pengungkapan kuantitatif dan pengungkapan kualitatif. Untuk pengungkapan kuantitatif dapat 
mencakup risiko likuiditas, risiko kredit, serta risiko pasar. Sedangkan pengungkapan kualitatif harus mengungkapkan segala tujuan, kebijakan serta segala eksposur risiko.

Selain itu, sesuai dengan Keputusan Ketua Badan Pengawas Pasar Modal Dan Lembaga Keuangan Nomor: Kep-431/BL/2012 tentang Kewajiban Penyampaian Laporan Tahunan bagi Emiten atau Perusahaan Publik dimana masing-masing perusahaan harus menerapkan sistem manajemen risiko yang mencakup berbagai jenis risiko dan cara pengelolaannya. Perusahaan juga dapat melakukan review atas efektivitas yang telah diterapkan oleh perusahaan setelah adanya sistem manajemen risiko yang sesuai.

Adanya dua peraturan tersebut maka perusahaan non-keuangan harus mengungkapkan walaupun pengungkapan risiko masih berupa himbauan karena pengungkapan risiko dilakukan secara sukarela. Hal tersebut yang menjadikan perusahaan non-keuangan cenderung akan menyajikan informasi risiko masih dalam konteks umum dan kurang terperinci. Sedangkan untuk perusahaan keuangan dituntut untuk jauh lebih ketat dalam hal praktik pengungkapan sukarela termasuk pengungkapan mengenai risiko dan pengungkapan mengenai keberadaan komite manajemen risiko.

Dalam penelitian ini, peneliti akan memilih perusahaan manufaktur yang merupakan perusahaan non-keuangan maka pengungkapan risiko yang dilakukan oleh perusahaan manufaktur masih bersifat sukarela. Pengungkapan risiko memiliki manfaat yaitu dapat meminimalisir terjadinya asimetri informasi antara principal dengan agen serta berperan untuk mewujudkan tata kelola perusahaan yang baik. Selain itu, pentingnya pengungkapan bagi pihak manajemen yaitu sebagai sarana dalam menjalin komunikasi kepada stakeholders atau pemegang saham terkait dengan tata kelola dan kinerja perusahaan (Aviolanda dan Rohman, 2016).

Mekanisme corporate governance merupakan mekanisme yang efektif untuk mengendalikan masalah-masalah mengenai keagenan dan memastikan bahwa manajer atau pihak internal tidak hanya memikirkan kepentingan dirinya sendiri namun juga mempertimbangkan kepentingan shareholders. Mekanisme corporate governance dapat diuji dengan melihat ukuran dewan komisaris yaitu seberapa banyak jumlah dewan komisaris yang dimiliki perusahaan, selain itu dilihat dari jumlah rapat yang dilakukan oleh para dewan komisaris dalam satu tahun. Beberapa penelitian terdahulu telah menguji bagaimana pengaruh corporate governance terhadap corporate risk disclosures dimana ditemukan hasil penelitiannya tidak konsisten atau beragam.

Corporate Risk Disclosures (CRD) juga dapat dipengaruhi oleh budaya perusahaan. Budaya perusahaan merupakan sekumpulan nilai yang dijadikan acuan atau kebiasaan dalam menjalankan tugas dan kewajiban di lingkup perusahaan. Cameron dan Quinn (1999) membagi budaya perusahaan menjadi empat kelompok yaitu budaya clan, budaya adhocracy, budaya market dan budaya hierarchy.

Penelitian ini merupakan pengembangan dari penelitian yang dilakukan oleh Atika (2016) namun terdapat perbedaan yaitu peneliti mengganti ukuran variabel pada mekanisme corporate governance yaitu ukuran dewan komisaris dan frekuensi rapat dewan komisaris. Alasan peneliti mengganti ukuran variabel pada mekanisme corporate governance, dimana dalam penelitian sebelumnya menunjukkan bahwa proporsi komisaris independen, frekuensi rapat komite audit dan kepemilikan institusional tidak berpengaruh terhadap pengungkapan risiko. Maka, peneliti tertarik untuk menguji ukuran variabel yang berbeda dengan menggunakan ukuran dewan komisaris dan frekuensi rapat dewan komisaris seperti pada penelitian yang dilakukan oleh Suhardjanto et al,. (2012).

Selain itu, peneliti akan membandingkan perusahaan manufaktur yang berada di Indonesia dengan perusahaan manufaktur yang berada di Malaysia. Peneliti mengacu pada perusahaan manufaktur karena aktivitas yang dijalankan perusahaan manufaktur semakin lama semakin kompleks sehingga akan menimbulkan risiko yang semakin meningkat pula, oleh karena itu sangat dibutuhkan adanya pengungkapan risiko.

Berdasarkan perbedaan diatas, peneliti tertarik untuk meneliti pengaruh beberapa variabel terhadap pengungkapan risiko dengan judul "Pengaruh Mekanisme Corporate Governance Dan Budaya Perusahaan Terhadap Corporate Risk Disclosures (Studi Komparatif pada Perusahaan Manufaktur yang Terdaftar di Bursa Efek Indonesia dan Bursa Malaysia Tahun 2016)”. 


\section{TINJAUAN LITERATUR DAN PERUMUSAN HIPOTESIS}

\section{Signalling Theory}

Signalling theory merupakan sebuah teori yang membahas bagaimana perusahaan memberikan signal-signal tentang keberhasilan atau kegagalan manajemen yang dapat berupa informasi laporan keuangan yang berfungsi sebagai alat analisis para investor untuk mengambil keputusan investasi (Suhardjanto et al., 2012). Signal berupa informasi yang diberikan harus lengkap, relevan, akurat dan tepat waktu sehingga para investor dapat mengetahui apakah manajemen telah melakukan kinerja seperti yang diharapkan atau belum (Atika, 2016).

\section{Agency Theory}

Agency theory menjelaskan bagaimana terjadinya hubungan antara principal dengan agen dimana principal merupakan pihak yang memberikan wewenang kepada agen sedangkan agen merupakan pihak yang menerima wewenang dari principal (Atika, 2016). Dalam teori ini menjelaskan bahwa setiap agen (manajer) memiliki informasi yang jauh lebih banyak dan akses yang tidak terbatas untuk mendapatkan informasi perusahaan sedangkan principal (investor) memiliki keterbatasan informasi dan hak akses terhadap informasi perusahaan.

\section{Stakeholders Theory}

Stakeholders Theory menjelaskan bahwa perusahaan memiliki hak untuk mengungkapan informasi secara sukarela termasuk informasi terkait pengungkapan risiko. Hal tersebut harus didasari oleh keinginan perusahaan itu sendiri dalam memberikan informasi lebih yang dapat bermanfaat bagi para stakeholders dalam mengambil keputusan.

Dalam konteks pengungkapan, perusahaan yang telah melakukan pengungkapan artinya perusahaan telah menyediakan informasi yang dibutuhkan dan dapat digunakan oleh para stakeholders. Perusahaan yang melakukan pengungkapan lebih banyak maka perusahaan mempunyai kemampuan yang tinggi untuk menghindari risiko yang mungkin saja terjadi (Yuniarti, 2016).

\section{Legitimacy Theory}

Legitimacy Theory dapat dijadikan dasar yang mampu menjelaskan alasan perusahaan melakukan pengungkapan sukarela yaitu meyakinkan masyarakat bahwa kegiatan perusahaan masih berada dalam batas dan norma masyarakat. Maka ketika terdapat perbedaan persepsi yang dianut masyarakat dan merugikan perusahaan maka perusahaan akan cenderung meningkatkan keinginan untuk memperbaiki atau melakukan perubahan dengan cara melakukan pelaporan atau pengungkapan secara sukarela terkait dengan informasi-informasi apa saja yang menjadi perhatian masyarakat termasuk informasi mengenai risiko perusahaan. Dengan harapan bahwa masyarakat dapat mengetahui apa saja kegiatan yang dilakukan perusahaan untuk tetap berjalan sesuai dengan batas dan norma di dalam lingkup sekitar.

\section{Pengaruh Ukuran Dewan Komisaris Terhadap Pengungkapan Risiko}

Dewan komisaris merupakan inti dari corporate governance dimana para dewan komisaris melakukan strategi, mengawasi manajemen, dan mewajibkan akuntabilitas untuk dapat terlaksana. Menurut penelitian yang telah dilakukan oleh Abeysekera (2008) jumlah dewan komisaris dikatakan efektif apabila berjumlah lebih dari 5 (lima) orang dan kurang dari 14 (empat belas) orang. Maka dapat diketahui bahwa semakin banyak jumlah dewan komisaris maka semakin baik perusahaan dapat terkontrol dengan pengawasan yang dilakukan oleh dewan komisaris. 
Dalam hal ini, Indonesia dan Malaysia menggunakan sistem yang berbeda yaitu Malaysia menggunakan sistem one-tier board sedangkan Indonesia menggunakan sistem two-tier board. Dalam one-tier system, hanya terdapat satu tempat dengan nama board of director (BOD), dimana peran dewan komisaris dan peran dewan direksi digabung menjadi satu. Di dalam two-tier system, terdapat dua wadah yang berbeda yaitu peran dewan komisaris dan dewan direksi dipisah secara jelas sehingga dewan komisaris akan mengawasi kerja dewan direksi.

$\boldsymbol{H}_{\text {ra }} \quad$ : Ukuran dewan komisaris berpengaruh positif terhadap Corporate Risk Disclosures di
Indonesia.

$\boldsymbol{H}_{l b} \quad$ : Ukuran dewan komisaris berpengaruh positif terhadap Corporate Risk Disclosures di Malaysia.

\section{Pengaruh Frekuensi Rapat Dewan Komisaris Terhadap Pengungkapan Risiko}

Dalam lingkup perusahaan non-keuangan khususnya manufaktur, ketentuan mengenai rapat dewan komisaris diatur dalam Piagam Dewan Komisaris, yang menetapkan bahwa penyelenggaraan rapat Dewan Komisaris dilakukan paling kurang 1 (satu) kali dalam setiap 2 (dua) bulan, dan rapat dewan komisaris bersama direksi paling kurang 1 (satu) kali dalam 4 (empat) bulan. Apabila rapat diselenggarakan secara rutin oleh dewan komisaris akan mendorong perusahaan untuk melakukan pengungkapan yang lebih luas guna memberikan informasi yang lebih kepada para pengguna terkait dengan risiko yang mungkin dihadapi oleh perusahaan.

\section{$\boldsymbol{H}_{2} \quad$ : Frekuensi rapat dewan komisaris berpengaruh positif terhadap corporate risk disclosures di Indonesia.}

$\boldsymbol{H}_{2 b} \quad$ : Frekuensi rapat dewan komisaris berpengaruh positif terhadap corporate risk disclosures di Malaysia.

\section{Pengaruh Budaya Clan Terhadap Pengungkapan Risiko}

Budaya clan merupakan budaya organisasi yang berfokus pada internal perusahaan yaitu berfokus kepada karyawan dan sumber daya manusia yang dimiliki dengan selalu berusaha untuk mengembangkan kompetensi terkait sumber daya manusia. Perusahaan dengan budaya clan yang tinggi akan lebih menekankan pada manfaat jangka panjang, dapat dilihat apabila karyawan yang bersangkutan merasa puas dan memiliki komitmen tinggi akan mampu menciptakan efektivitas yang tinggi pula. Pada penelitian yang dilakukan oleh ElKelish dan Hassan (2014) menyatakan bahwa budaya clan tidak berpengaruh terhadap pengungkapan risiko. Didukung dengan penelitian yang dilakukan oleh Atika (2016) menunjukkan bahwa budaya clan tidak berpengaruh terhadap pengungkapan risiko.

Budaya clan hampir sama dengan tipe organisasi yang dimiliki oleh keluarga yang memusatkan kewenangannya pada orang-orang tertentu saja entah satu aliran darah maupun saudara persusuan. Hal tersebut akan menimbulkan rendahnya tingkat formalitas dan ambiguitas pengungkapan informasi termasuk informasi mengenai risiko perusahaan. Maka ketika budaya clan di suatu perusahaan tersebut tinggi perusahaan cenderung melakukan pengungkapan risiko yang rendah. Berdasarkan uraian diatas, maka dapat diturunkan hipotesis:

\section{$\boldsymbol{H}_{3 a} \quad$ : Budaya Clan berpengaruh negatif terhadap corporate risk disclosures di Indonesia \\ $\boldsymbol{H}_{s b} \quad$ : Budaya Clan berpengaruh negatif terhadap corporate risk disclosures di Malaysia}




\section{Pengaruh Budaya Adhocracy Terhadap Pengungkapan Risiko}

Budaya adhocracy berfokus pada lingkungan eksternal dengan melihat bagaimana kesempatan pasar di masa depan, perluasan lini produk yang inovatif, dan pengembangan teknologi baru (Fiordelisi dan Ricci, 2014). Budaya adhocracy akan mendorong setiap individu untuk lebih kreatif sehingga dapat bersaing di lingkungan eksternal. Penelitian yang telah dilakukan oleh ElKelish dan Hassan (2014) menyatakan bahwa budaya adhocracy tidak berpengaruh terhadap pengungkapan risiko. Didukung dengan penelitian yang dilakukan oleh Atika (2016) yang menunjukkan bahwa budaya adhocracy tidak berpengaruh terhadap pengungkapan risiko.

Budaya adhocracy diharapkan memiliki tingkat pengungkapan risiko yang rendah guna mengurangi biaya yang mungkin muncul sehingga perusahaan dapat tetap menjadi penyedia utama lini produk yang inovatif. Dengan demikian, semakin budaya adhocracy diterapkan perusahaan tinggi, maka tingkat pengungkapan risiko yang dilakukan akan semakin rendah. Berdasarkan uraian diatas, maka dapat diturunkan hipotesis:

\section{$\boldsymbol{H}_{\text {ta }} \quad$ : Budaya Adhocracy berpengaruh negatif terhadap corporate risk disclosures di Indonesia \\ $\boldsymbol{H}_{\star b} \quad:$ Budaya Adhocracy berpengaruh negatif terhadap corporate risk disclosures di Malaysia}

\section{Pengaruh Budaya Market Terhadap Pengungkapan Risiko}

Budaya market berfokus pada transaksi dengan para pihak eksternal perusahaan seperti pemasok, pelanggan dan lain-lain. Tujuan utama dari budaya market adalah menciptakan keunggulan bersaing perusahaan melalui transaksi yang mengedepankan produktivitas yang akan menghasilkan keuntungan.

Keberhasilan perusahaan dapat dinilai dengan melihat harga saham, setelah perusahaan mengetahui harga saham menjadi patokan maka perusahaan akan melakukan sebuah pengungkapan. Pengungkapan yang dilakukan akan bersifat lebih luas untuk mendorong terciptanya kepuasan pasar yang dapat meningkatkan harga saham dan perusahaan mampu menjadi market leader.

\section{$\boldsymbol{H}_{s a} \quad$ : Budaya Market berpengaruh positif terhadap corporate risk disclosures di Indonesia \\ $\boldsymbol{H}_{s \triangleright} \quad$ : Budaya Market berpengaruh positif terhadap corporate risk disclosures di Malaysia.}

\section{Pengaruh Budaya Hierarchy Terhadap Pengungkapan Risiko}

Budaya hierarchy berfokus pada internal dan mengedepankan efektivitas perusahaan dengan cara mengimplementasikan kebijakannya dengan aturan dan prosedur yang ketat. Terdapat beberapa strategi yang dapat dijadikan acuan adalah pendeteksian kesalahan, peningkatan pengukuran, pengendalian proses, dan pemecahan masalah yang sistematik. Penelitian yang dilakukan oleh ElKelish dan Hassan (2014) menyatakan bahwa budaya hierarchy berpengaruh positif terhadap pengungkapan risiko. Didukung oleh penelitian yang dilakukan oleh Atika (2016) yang menunjukkan bahwa budaya hierarchy berpengaruh positif terhadap pengungkapan risiko.

Perusahaan dengan budaya hierarchy akan melakukan pengungkapan risiko yang lebih luas untuk menjaga efisiensi terkait operasional perusahaan. Ketika budaya hierarchy perusahaan tersebut tinggi maka perusahaan akan melakukan pengungkapan risiko semakin tinggi pula. Berdasarkan uraian diatas, maka dapat diturunkan hipotesis:

\section{$\boldsymbol{H}_{\sigma_{a}} \quad$ : Budaya Hierarchy berpengaruh positif terhadap corporate risk disclosures di Indonesia}


$\boldsymbol{H}_{\text {ob }} \quad$ : Budaya Hierarchy berpengaruh positif terhadap corporate risk disclosures di Malaysia

\section{METODE PENELITIAN}

Populasi dalam penelitian ini adalah perusahaan yang terdaftar di Bursa Efek Indonesia (BEI) dan Bursa Malaysia tahun 2016. Sampel pada penelitian ini akan berfokus pada perusahaan manufaktur dimana perusahaan manufaktur merupakan perusahaan non-keuangan. Data yang digunakan adalah data sekunder yang diperoleh berasal dari Bursa Efek Indonesia (BEI) atau Bursa Malaysia tahun 2016 maupun data yang berasal dari situs resmi perusahaan yang bersangkutan. Teknik pengumpulan data pada penelitian ini dilakukan dengan cara dokumentasi. Pengumpulan data diambil dari laporan tahunan perusahaan yang menjadi sampel penelitian. Dalam penelitian ini menggunakan metode content analysis yaitu berdasarkan kalimat yang sesuai dengan kriteria atau check list yang menggambarkan pengungkapan risiko.

\section{HASIL DAN PEMBAHASAN}

\section{Gambaran Umum Objek/Subyek Penelitian}

Perusahaan yang menjadi objek dalam penelitian ini adalah perusahaan manufaktur yang terdaftar di Bursa Efek Indonesia (BEI) dan Bursa Malaysia tahun 2016.

Tabel 1.1 Proses Pengambilan Sampel Indonesia

\begin{tabular}{llc}
\hline No. & \multicolumn{1}{c}{ Uraian } & Jumlah \\
\hline 1 & Perusahaan manufaktur yang terdaftar di BEI tahun 2016 & 144 \\
2 & Perusahaan yang belum menerbitkan laporan tahunan tahun & $(15)$ \\
& 2016 & \\
3 & $\begin{array}{l}\text { Perusahaan yang mengungkapkan laporan dalam bentuk } \\
\text { non-rupiah }\end{array}$ & $(25)$ \\
4 & $\begin{array}{l}\text { Perusahaan yang memiliki laba negatif (rugi) } \\
\text { Perusahaan yang tidak memiliki data lengkap yang }\end{array}$ & $(27)$ \\
5 & dibutuhkan peneliti & \\
Total sampel perusahaan yang diteliti & 55 \\
\hline
\end{tabular}

Tabel 1.2 Proses Pengambilan Sampel Malaysia

\begin{tabular}{|c|c|c|}
\hline No. & Uraian & Jumlah \\
\hline 1 & Perusahaan yang terdaftar di Bursa Malavsia tahun 2016 & 806 \\
\hline 2 & $\begin{array}{l}\text { Perusahaan yang belum menerbitkan laporan tahunan tahun } \\
2016\end{array}$ & (55) \\
\hline 3 & Perusahaan non-manufaktur & (593) \\
\hline 4 & Perusahaan yang memiliki laba negatif (rugi) & (28) \\
\hline 5 & $\begin{array}{lrllll}\text { Perusahaan yang tidak memiliki data lengkap yang } \\
\text { dibutuhkan peneliti }\end{array}$ & (45) \\
\hline & Total sampel perusahaan yang diteliti & 85 \\
\hline
\end{tabular}

\section{Analisis Statistik Deskriptif}

Berdasarkan Tabel 1.3 diketahui bahwa jumlah sampel masing-masing variabel adalah sebanyak 55 perusahaan. Variabel ukuran dewan komisaris memiliki nilai minimal sebesar 2,0000, nilai maksimal sebesar 8,0000, dengan nilai rata-rata sebesar 4,2000 dan standar deviasi sebesar 1,6262. Artinya, paling sedikit perusahaan memiliki jumlah dewan komisaris 2 orang dan paling tinggi memiliki jumlah dewan komisaris 8 orang dengan rata-rata perusahaan memiliki 
jumlah dewan komisaris sejumlah 4 orang. Variabel frekuensi rapat dewan komisaris memiliki nilai minimal sebesar 1,0000 dan nilai maksimal 24,0000 dengan nilai rata-rata sebesar 5,9454 dan standar deviasi sebesar 3,5088. Artinya, perusahaan mengadakan rapat dewan komisaris paling sedikit 1 kali dan paling banyak 24 kali dalam satu tahun dengan rata-rata keseluruhan adalah 6 kali.

Tabel 1.3 Descriptive Statistics Indonesia

\begin{tabular}{llllll}
\hline & & Minimum & Maximum & Mean & $\begin{array}{c}\text { Std. } \\
\text { Deviation }\end{array}$ \\
\hline UDK & 55 & 2.0000 & 8.0000 & 4.200000 & 1.6261748 \\
FRDK & 55 & 1.0000 & 24.0000 & 5.945455 & 3.5088153 \\
CLAN & 55 & .0475 & .5400 & .225573 & .1256835 \\
ADHO & 55 & 9.3432 & 28.3472 & 19.858371 & 5.7290432 \\
MRKT & 55 & .0024 & .3571 & .082243 & .0754232 \\
HIRC & 55 & .0082 & 2.1529 & .254708 & .4576676 \\
CRD & 55 & .5333 & .8444 & .675556 & .0625038 \\
Valid N & 55 & & & & \\
(listwise) & & & & & \\
\hline
\end{tabular}

Variabel budaya clan memiliki nilai minimal sebesar 0,0475, nilai maksimal sebesar 0,5400 dengan nilai rata-rata sebesar 0,2256 dan standar deviasi sebesar 0,1257. Artinya, proporsi gaji dan tunjangan karyawan perusahaan terhadap beban operasi perusahaan paling rendah sebesar $4,75 \%$, paling tinggi sebesar $54,00 \%$ dan rata-rata sebesar $22,56 \%$. Variabel budaya adhocracy memiliki nilai minimal sebesar 9,3432, nilai maksimal sebesar 28,3472 dengan nilai rata-rata sebesar 19,8584 dan standar deviasi sebesar 5,7290. Artinya, perubahan laba operasi tahun 2016 dengan tahun sebelumnya paling rendah adalah 9,3432, paling tinggi adalah 28,3472 dan rata-rata adalah sebesar 19,8584.

Variabel budaya market memiliki nilai minimal sebesar 0,0024, nilai maksimal sebesar 0,3571 dengan nilai rata-rata sebesar 0,0822 dan standar deviasi sebesar 0,0754. Artinya, tingkat pengembalian investasi perusahaan paling rendah adalah sebesar 0,0024, paling tinggi adalah sebesar 0,3571, dan rata-rata adalah sebesar 0,0822. Variabel budaya hierarchy memiliki nilai minimal sebesar 0,0082, nilai maksimal sebesar 2,1529 dengan nilai rata-rata sebesar 0,2547 dan standar deviasi sebesar 0,4577. Artinya, proporsi biaya tenaga kerja yang berhubungan dengan transaksi terhadap laba bersih perusahaan paling rendah adalah sebesar 0,0082 , paling tinggi adalah 2,1529, dengan rata-rata sebesar 0,2547.

Variabel corporate risk disclosure memiliki nilai minimal sebesar 0,5333, nilai maksimal sebesar 0,8444 dengan nilai rata-rata sebesar 0,6756 dan standar deviasi sebesar 0,0625. Artinya, paling rendah perusahaan mengungkapkan risiko sebanyak 53,33\% dan paling tinggi adalah sebanyak 84,44 \% dari total item pengungkapan risiko perusahaan.

Tabel 1.4 Descriptive Statistics Malaysia

\begin{tabular}{|c|c|c|c|c|c|}
\hline & $\mathrm{N}$ & Minimum & Maximum & Mean & $\begin{array}{c}\text { Std. } \\
\text { Deviation }\end{array}$ \\
\hline UDK & 85 & 2.0000 & 8.0000 & 4.494118 & 1.3682064 \\
\hline FRDK & 85 & 2.0000 & 10.0000 & 5.047059 & 1.3793190 \\
\hline CLAN & 85 & .0025 & .8506 & .110886 & .1152534 \\
\hline ADHO & 85 & 5.0000 & 19.0000 & 12.894118 & 3.2587740 \\
\hline MRKT & 85 & .0009 & .9584 & .118970 & .1458535 \\
\hline HIRC & 85 & .0008 & .9494 & .332639 & .3015424 \\
\hline CRD & 85 & .6222 & .7556 & .688627 & .0376397 \\
\hline $\begin{array}{l}\text { Valid N } \\
\text { (listwise) }\end{array}$ & 85 & & & & \\
\hline
\end{tabular}


Berdasarkan Tabel 1.4 diketahui bahwa jumlah sampel masing-masing variabel adalah sebanyak 85 perusahaan. Variabel ukuran dewan komisaris memiliki nilai minimal sebesar 2,0000, nilai maksimal sebesar 8,0000, dengan nilai rata-rata sebesar 4,4941 dan standar deviasi sebesar 1,3682. Artinya, paling sedikit perusahaan memiliki jumlah dewan komisaris yang tercantum di Board of Director adalah 2 orang dan paling tinggi adalah 8 orang dengan rata-rata sejumlah 4 orang. Variabel frekuensi rapat dewan komisaris memiliki nilai minimal sebesar 2,0000 dan nilai maksimal 10,0000 dengan nilai rata-rata sebesar 5,0471 dan standar deviasi sebesar 1,3793. Artinya, perusahaan mengadakan rapat dewan komisaris paling sedikit 2 kali dan paling banyak $10 \mathrm{kali}$ dalam satu tahun dengan rata-rata keseluruhan adalah 5 kali. Variabel budaya clan memiliki nilai minimal sebesar 0,0025, nilai maksimal sebesar 0,8506 dengan nilai rata-rata sebesar 0,1109 dan standar deviasi sebesar 0,1153. Artinya, proporsi gaji dan tunjangan karyawan perusahaan terhadap beban operasi perusahaan paling rendah sebesar 0,25\%, paling tinggi sebesar 85,06\% dan rata-rata sebesar 11,09\%. Variabel budaya adhocracy memiliki nilai minimal sebesar 5,0000, nilai maksimal sebesar 19,0000 dengan nilai rata-rata sebesar 12,8941 dan standar deviasi sebesar 3,2588. Artinya, perubahan laba operasi tahun 2016 dengan tahun sebelumnya paling rendah adalah 5,0000, paling tinggi adalah 19,0000 dan rata-rata adalah sebesar 12,8941.

Variabel budaya market memiliki nilai minimal sebesar 0,0009, nilai maksimal sebesar 0,9584 dengan nilai rata-rata sebesar 0,1190 dan standar deviasi sebesar 0,1459. Artinya, tingkat pengembalian investasi perusahaan paling rendah adalah sebesar 0,0009, paling tinggi adalah sebesar 0,9584 , dan rata-rata adalah sebesar 0,1190 . Variabel budaya hierarchy memiliki nilai minimal sebesar 0,0008, nilai maksimal sebesar 0,9494 dengan nilai rata-rata sebesar 0,3326 dan standar deviasi sebesar 0,3015. Artinya, proporsi biaya tenaga kerja yang berhubungan dengan transaksi terhadap laba bersih perusahaan paling rendah adalah sebesar 0,0008, paling tinggi adalah 0,9494, dengan rata-rata sebesar 0,3326.

Variabel corporate risk disclosure memiliki nilai minimal sebesar 0,6222 , nilai maksimal sebesar 0,7556 dengan nilai rata-rata sebesar 0,6886 dan standar deviasi sebesar 0,0376. Artinya, paling rendah perusahaan mengungkapkan risiko perusahaan sebanyak $62,22 \%$ dan paling tinggi adalah sebanyak 75,56\% dari total item pengungkapan risiko perusahaan.

\section{Uji Asumsi Klasik}

\section{Uji Normalitas}

Tabel 1.5 One-Sample Kolmogorov-Smirnov Test Indonesia

\begin{tabular}{llr}
\hline & & \multicolumn{2}{c}{$\begin{array}{c}\text { Unstandardize d } \\
\text { Residual }\end{array}$} \\
\hline $\mathrm{N}$ & & 55 \\
Normal Parameters(a,b) & Mean & .0000000 \\
Most Extreme & Std. Deviation & .05723444 \\
Differences & Absolute & .083 \\
& Positive & .066 \\
Kolmogorov-Smirnov Z & Negative & -.083 \\
Asymp. Sig. (2-tailed) & & .613 \\
\hline
\end{tabular}

Uji normalitas digunakan untuk memastikan bahwa residual dalam model regresi memiliki distribusi normal. Residual dapat dikatakan berdistribusi normal apabila nilai Asymp. Sig (2-tailed) $>$ alpha 0,05. Berdasarkan hasil uji one-sample Kolmogorov-smirnov (KS) pada Tabel 4.5 diketahui bahwa nilai Asymp. Sig (2-tailed) sebesar 0,847 > alpha 0,05 maka dapat disimpulkan bahwa residual penelitian berdistribusi normal. 
Tabel 1.6 One-Sample Kolmogorov-Smirnov Test Malaysia

\begin{tabular}{llr}
\hline & & \multicolumn{2}{c}{$\begin{array}{c}\text { Unstandardize d } \\
\text { Residual }\end{array}$} \\
\hline $\mathrm{N}$ & Mean & 85 \\
Normal Parameters(a,b) & Std. Deviation & .0000000 \\
Most Extreme & Absolute & .03563966 \\
Differences & Positive & .084 \\
& Negative & .079 \\
Kolmogorov-Smirnov Z & & -.084 \\
Asymp. Sig. (2-tailed) & & .772 \\
\hline
\end{tabular}

Uji normalitas digunakan untuk memastikan bahwa residual dalam model regresi memiliki distribusi normal. Residual dapat dikatakan berdistribusi normal apabila nilai Asymp. Sig (2-tailed) $>$ alpha 0,05. Berdasarkan hasil uji one-sample Kolmogorov-smirnov (KS) pada Tabel 4.5 diketahui bahwa nilai Asymp. Sig (2-tailed) sebesar 0,590 > alpha 0,05 maka dapat disimpulkan bahwa residual penelitian berdistribusi normal.

\section{Uji Multikolinearitas}

Tabel 1.7 Uji Multikolinearitas Indonesia

\begin{tabular}{|c|c|c|c|c|c|c|}
\hline \multirow[t]{2}{*}{ Mode } & & \multicolumn{2}{|c|}{$\begin{array}{l}\text { Unstandardized } \\
\text { Coefficients }\end{array}$} & \multirow[b]{2}{*}{ Sig. } & \multicolumn{2}{|c|}{ Collinearity Statistics } \\
\hline & & $\mathrm{B}$ & Std. Error & & Tolerance & VIF \\
\hline \multirow[t]{7}{*}{1} & (Constant) & .619 & .045 & .000 & & \\
\hline & UDK & .013 & .005 & .017 & .904 & 1.107 \\
\hline & FRDK & .001 & .003 & .630 & .865 & 1.156 \\
\hline & CLAN & -.030 & .069 & .665 & .919 & 1.088 \\
\hline & $\mathrm{ADHO}$ & .001 & .001 & .703 & .940 & 1.063 \\
\hline & MRKT & -.104 & .116 & .371 & .897 & 1.115 \\
\hline & HIRC & -.010 & .018 & .603 & .957 & 1.045 \\
\hline
\end{tabular}

Uji multikolinearitas digunakan untuk menguji apakah terjadi korelasi antar variabel independen. Data tidak terkena multikolinearitas apabila nilai VIF $<10$. Berdasarkan Tabel 1.7 dapat diketahui bahwa nilai VIF semua variabel $<10$ maka dapat disimpulkan bahwa data tidak terjadi multikolinearitas.

Tabel 1.8 Uji Multikolinearitas Malaysia

\begin{tabular}{|c|c|c|c|c|c|c|}
\hline \multicolumn{2}{|c|}{ Model } & \multicolumn{2}{|c|}{$\begin{array}{l}\text { Unstandardized } \\
\text { Coefficients }\end{array}$} & \multirow[b]{2}{*}{ Sig. } & \multicolumn{2}{|c|}{ Collinearity Statistics } \\
\hline & & $\mathrm{B}$ & Std. Error & & Tolerance & VIF \\
\hline \multirow[t]{7}{*}{1} & (Constant) & .729 & .027 & .000 & & \\
\hline & UDK & .000 & .003 & .897 & .883 & 1.133 \\
\hline & FRDK & -.002 & .003 & .616 & .898 & 1.114 \\
\hline & CLAN & -.067 & .036 & .067 & .942 & 1.061 \\
\hline & $\mathrm{ADHO}$ & -.002 & .001 & .196 & .874 & 1.145 \\
\hline & MRKT & .006 & .029 & .836 & .898 & 1.113 \\
\hline & HIRC & -.016 & .014 & .264 & .917 & 1.090 \\
\hline
\end{tabular}

a Dependent Variable: CRD 


\section{Uji Heteroskedastisitas}

Tabel 1.9 Uji Heteroskedastisitas Indonesia

\begin{tabular}{|c|c|c|c|c|c|c|c|c|c|}
\hline & & & UDK & FRDK & CLAN & ADHO & MRKT & HIRC & $\begin{array}{c}\text { ABS } \\
\text { RES }\end{array}$ \\
\hline \multirow{22}{*}{$\begin{array}{l}\text { Spe } \\
\text { arm } \\
\text { an's } \\
\text { rho }\end{array}$} & UDK & $\begin{array}{l}\text { Correlation } \\
\text { Coefficient }\end{array}$ & 1.000 & $.333\left(^{*}\right)$ & -.047 & -.038 & -.173 & -.020 & .028 \\
\hline & & Sig. (2-tailed) & & .013 & .732 & .782 & .206 & .883 & .840 \\
\hline & & $\mathrm{N}$ & 55 & 55 & 55 & 55 & 55 & 55 & 55 \\
\hline & FRDK & $\begin{array}{l}\text { Correlation } \\
\text { Coefficient }\end{array}$ & $.333\left(^{*}\right)$ & 1.000 & .146 & -.197 & .100 & -.074 & .084 \\
\hline & & Sig. (2-tailed) & .013 & & .289 & .149 & .469 & .590 & .543 \\
\hline & & $\mathrm{N}$ & 55 & 55 & 55 & 55 & 55 & 55 & 55 \\
\hline & CLAN & $\begin{array}{l}\text { Correlation } \\
\text { Coefficient }\end{array}$ & -.047 & .146 & 1.000 & .189 & -.177 & .052 & -.224 \\
\hline & & Sig. (2-tailed) & .732 & .289 & & .167 & .197 & .704 & .100 \\
\hline & & $\mathrm{N}$ & 55 & 55 & 55 & 55 & 55 & 55 & 55 \\
\hline & ADHO & $\begin{array}{l}\text { Correlation } \\
\text { Coefficient }\end{array}$ & -.038 & -.197 & .189 & 1.000 & -.168 & .097 & -.080 \\
\hline & & Sig. (2-tailed) & .782 & .149 & .167 & & .221 & .480 & .563 \\
\hline & & $\mathrm{N}$ & 55 & 55 & 55 & 55 & 55 & 55 & 55 \\
\hline & MRKT & $\begin{array}{l}\text { Correlation } \\
\text { Coefficient }\end{array}$ & -.173 & .100 & -.177 & -.168 & 1.000 & -.037 & .134 \\
\hline & & Sig. (2-tailed) & .206 & .469 & .197 & .221 & & .787 & .328 \\
\hline & & $\mathrm{N}$ & 55 & 55 & 55 & 55 & 55 & 55 & 55 \\
\hline & HIRC & $\begin{array}{l}\text { Correlation } \\
\text { Coefficient }\end{array}$ & -.020 & -.074 & .052 & .097 & -.037 & 1.000 & -.089 \\
\hline & & Sig. (2-tailed) & .883 & .590 & .704 & .480 & .787 & . & .518 \\
\hline & & $\mathrm{N}$ & 55 & 55 & 55 & 55 & 55 & 55 & 55 \\
\hline & ABS_RE & Correlation & .028 & .084 & -.224 & -.080 & .134 & -.089 & 1.000 \\
\hline & $S$ & Coefficient & & & & & & & \\
\hline & & Sig. (2-tailed) & .840 & .543 & .100 & .563 & .328 & .518 & \\
\hline & & $\mathrm{N}$ & 55 & 55 & 55 & 55 & 55 & 55 & 55 \\
\hline
\end{tabular}

Uji multikolinearitas digunakan untuk menguji apakah terjadi korelasi antar variabel independen. Data tidak terkena multikolinearitas apabila nilai VIF $<10$. Berdasarkan Tabel 1.8 dapat diketahui bahwa nilai VIF semua variabel $<10$ maka dapat disimpulkan bahwa data tidak terjadi multikolinearitas.

Uji heteroskedastisitas digunakan untuk menguji apakah terjadi ketidaksamaan variance. Data tidak terkena heteroskedastisitas apabila nilai sig > alpha 0,05. Berdasarkan Tabel 1.9 dapat diketahui bahwa nilai sig seluruh variabel penelitian lebih besar dari alpha 0,05 maka dapat disimpulkan bahwa data tidak terjadi heteroskedastisitas.

Uji heteroskedastisitas digunakan untuk menguji apakah terjadi ketidaksamaan variance. Data tidak terkena heteroskedastisitas apabila nilai sig > alpha 0,05. Berdasarkan Tabel 4.10 dapat diketahui bahwa nilai sig seluruh variabel penelitian lebih besar dari alpha 0,05 maka dapat disimpulkan bahwa data tidak terjadi heteroskedastisitas. 
Tabel 1.10 Uji Heteroskedastisitas Malaysia

\begin{tabular}{|c|c|c|c|c|c|c|c|c|c|}
\hline & & & $\begin{array}{l}\mathrm{ABS}_{-} \\
\mathrm{RES}\end{array}$ & UDK & FRDK & CLAN & ADHO & MRKT & HIRC \\
\hline \multirow{22}{*}{$\begin{array}{l}\text { Spe } \\
\text { arm } \\
\text { an's } \\
\text { rho }\end{array}$} & $\begin{array}{l}\text { ABS_R } \\
\text { ES }\end{array}$ & $\begin{array}{l}\text { Correlation } \\
\text { Coefficient }\end{array}$ & 1.000 & .015 & .004 & .103 & -.018 & .021 & .089 \\
\hline & & Sig. (2-tailed) & & .892 & .968 & .348 & .872 & .850 & .420 \\
\hline & & $\mathrm{N}$ & 85 & 85 & 85 & 85 & 85 & 85 & 85 \\
\hline & UDK & Correlation & & & & - & & & \\
\hline & & Coefficient & .015 & 1.000 & .172 & $.217\left(^{*}\right.$ & -.157 & .023 & .022 \\
\hline & & Sig. (2-tailed) & .892 & & .115 & .046 & .150 & .835 & .839 \\
\hline & & $\mathrm{N}$ & 85 & 85 & 85 & 85 & 85 & 85 & 85 \\
\hline & FRDK & $\begin{array}{l}\text { Correlation } \\
\text { Coefficient }\end{array}$ & .004 & .172 & 1.000 & -.158 & -.023 & -.053 & .173 \\
\hline & & Sig. (2-tailed) & .968 & .115 & & .149 & .837 & .633 & .114 \\
\hline & & $\mathrm{N}$ & 85 & 85 & 85 & 85 & 85 & 85 & 85 \\
\hline & CLAN & $\begin{array}{l}\text { Correlation } \\
\text { Coefficient }\end{array}$ & .103 & $-.217\left(^{*}\right)$ & -.158 & 1.000 & .150 & .091 & -.030 \\
\hline & & Sig. (2-tailed) & .348 & .046 & .149 & & .170 & .406 & .787 \\
\hline & & $\mathrm{N}$ & 85 & 85 & 85 & 85 & 85 & 85 & 85 \\
\hline & $\mathrm{ADHO}$ & $\begin{array}{l}\text { Correlation } \\
\text { Coefficient }\end{array}$ & -.018 & -.157 & -.023 & .150 & 1.000 & .202 & $.257\left(^{*}\right.$ \\
\hline & & Sig. (2-tailed) & .872 & .150 & .837 & .170 & & .064 & .018 \\
\hline & & $\mathrm{N}$ & 85 & 85 & 85 & 85 & 85 & 85 & 85 \\
\hline & MRKT & $\begin{array}{l}\text { Correlation } \\
\text { Coefficient }\end{array}$ & .021 & .023 & -.053 & .091 & .202 & 1.000 & -.124 \\
\hline & & Sig. (2-tailed) & .850 & .835 & .633 & .406 & .064 & & .259 \\
\hline & & $\mathrm{N}$ & 85 & 85 & 85 & 85 & 85 & 85 & 85 \\
\hline & HIRC & $\begin{array}{l}\text { Correlation } \\
\text { Coefficient }\end{array}$ & .089 & .022 & .173 & -.030 & $.257\left(^{*}\right)$ & -.124 & 1.000 \\
\hline & & Sig. (2-tailed) & .420 & .839 & .114 & .787 & .018 & .259 & \\
\hline & & $\mathrm{N}$ & 85 & 85 & 85 & 85 & 85 & 85 & 85 \\
\hline
\end{tabular}

\section{Uji Hipotesis}

Uji Koefisien Determinasi

Tabel 1.11 Uji Koefisien Determinasi Indonesia

\begin{tabular}{clccc}
\hline Model & R & R Square & $\begin{array}{c}\text { Adjusted R } \\
\text { Square }\end{array}$ & $\begin{array}{c}\text { Std. Error of the } \\
\text { Estimate }\end{array}$ \\
\hline 1 & $.402(\mathrm{a})$ & .162 & .057 & .0607063 \\
\hline
\end{tabular}

a Predictors: (Constant), HIRC, UDK, MRKT, ADHO, CLAN, FRDK

b Dependent Variable: CRD

Berdasarkan Tabel 1.11 dapat diketahui bahwa nilai Adjusted $R$ Square sebesar 0,057 atau $5,7 \%$. Artinya, variabel independen mampu menjelaskan 5,7\% variabel dependen. Selebihnya yaitu $94,3 \%$ dijelaskan oleh variabel lain diluar variabel penelitian.

Berdasarkan Tabel 1.12 dapat diketahui bahwa nilai Adjusted $R$ Square sebesar 0,034 atau $3,4 \%$. Artinya, variabel independen mampu menjelaskan 3,4\% variabel dependen. Selebihnya yaitu $96,4 \%$ dijelaskan oleh variabel lain diluar variabel penelitian. 
Tabel 1.12 Uji Koefisien Determinasi Malaysia

\begin{tabular}{|c|c|c|c|c|}
\hline Model & $\mathrm{R}$ & R Square & Adjusted R Square & $\begin{array}{l}\text { Std. Error of the } \\
\text { Estimate }\end{array}$ \\
\hline 1 & $.322(\mathrm{a})$ & .103 & .034 & .0369850 \\
\hline
\end{tabular}

a Predictors: (Constant), HIRC, MRKT, CLAN, UDK, FRDK, ADHO

b Dependent Variable: CRD

Uji Signifikansi Simultan (Uji ‡)

Tabel 4.13 Uji f Indonesia

\begin{tabular}{lllrrrr}
\hline Model & & \multicolumn{2}{c}{ Sum of } & & & \\
Squares & df & Mean Square & F & Sig. \\
\hline 1 & Regression & .034 & 6 & .006 & 1.541 & $.185(\mathrm{a})$ \\
& Residual & .177 & 48 & .004 & & \\
& Total & .211 & 54 & & & \\
\hline
\end{tabular}

a Predictors: (Constant), HIRC, UDK, MRKT, ADHO,

CLAN, FRDK b Dependent Variable: CRD

Uji $f$ menguji pengaruh simultan seluruh variabel independen terhadap variabel dependen dalam model regresi. Variabel independen memiliki pengaruh secara simultan apabila nilai sig < alpha 0,05. Berdasarkan Tabel 1.13 dapat diketahui bahwa nilai sig sebesar 0,185> alpha 0,05 maka dapat disimpulkan bahwa tidak terdapat pengaruh simultan antara variabel ukuran dewan komisaris, frekuensi rapat dewan komisaris, budaya clan, budaya adhocracy, budaya market, dan budaya hierarchy terhadap variabel corporate risk disclosure.

Tabel 1.14 Uji f Malaysia

\begin{tabular}{lllrrrc}
\hline Model & & \multicolumn{2}{c}{ Sum of } & & & \\
Squares & df & Mean Square & F & Sig. \\
\hline 1 & Regression & .012 & 6 & .002 & 1.500 & .189 (a) \\
& Residual & .107 & 78 & .001 & & \\
& Total & .119 & 84 & & & \\
\hline
\end{tabular}

a Predictors: (Constant), HIRC, MRKT, CLAN, UDK, FRDK,

ADHO b Dependent Variable: CRD

Uji $f$ menguji pengaruh simultan seluruh variabel independen terhadap variabel dependen dalam model regresi. Variabel independen memiliki pengaruh secara simultan apabila nilai sig < alpha 0,05. Berdasarkan Tabel 1.14 dapat diketahui bahwa nilai sig sebesar 0,189 > alpha 0,05 maka dapat disimpulkan bahwa tidak terdapat pengaruh simultan antara variabel ukuran dewan komisaris, frekuensi rapat dewan komisaris, budaya clan, budaya adhocracy, budaya market.

\section{Uji Signifikansi Parameter Individual (Uji t)}

Uji signifikansi parameter individual (uji t) dilakukan untuk menguji pengaruh parsial variabel independen dalam model regresi terhadap variabel dependen.

Tabel 1.15 Uji t Indonesia

\begin{tabular}{|c|c|c|c|c|c|c|}
\hline \multicolumn{2}{|c|}{ Model } & \multicolumn{2}{|c|}{$\begin{array}{c}\text { Unstandardized } \\
\text { Coefficients }\end{array}$} & $\begin{array}{c}\text { Standardized } \\
\text { Coefficients }\end{array}$ & $\mathrm{t}$ & Sig. \\
\hline \multirow{8}{*}{1} & & & & & & \\
\hline & (Constant) & .619 & .045 & & 13.639 & .000 \\
\hline & UDK & .013 & .005 & .344 & 2.474 & .017 \\
\hline & FRDK & .001 & .003 & .069 & .485 & .630 \\
\hline & CLAN & -.030 & .069 & -.060 & -.436 & .665 \\
\hline & ADHO & .001 & .001 & .052 & .383 & .703 \\
\hline & MRKT & -.104 & .116 & -.126 & -.903 & .371 \\
\hline & HIRC & -.010 & .018 & -.071 & -.524 & .603 \\
\hline
\end{tabular}

a Dependent Variable: CRD 


\section{Ukuran Dewan Komisaris dan Corporate Risk Disclosure}

Berdasarkan Tabel 1.15 dapat diketahui bahwa nilai sig variabel ukuran dewan komisaris (UDK) adalah sebesar 0,017 dengan nilai koefisien regresi sebesar 0,013. Nilai sig 0,017 < alpha 0,05 menunjukkan bahwa variabel ukuran dewan komisaris (UDK) memiliki pengaruh yang signifikan terhadap corporate risk disclosure (CRD). Sehingga, hipotesis pertama ( ) diterima.

\section{Frekuensi Rapat Dewan Komisaris dan Corporate Risk Disclosure}

Berdasarkan Tabel 4.15 dapat diketahui bahwa nilai sig variabel frekuensi rapat dewan komisaris (FRDK) adalah sebesar 0,630 dengan nilai koefisien regresi sebesar 0,001. Nilai sig 0,630 $>$ alpha 0,05 menunjukkan bahwa variabel frekuensi rapat dewan komisaris (FRDK) tidak memiliki pengaruh yang signifikan terhadap corporate risk disclosure (CRD). Sehingga, hipotesis kedua () ditolak.

\section{Budaya Clan dan Corporate Risk Disclosure}

Berdasarkan Tabel 4.15 dapat diketahui bahwa nilai sig variabel budaya clan (CLAN) adalah sebesar 0,665 dengan nilai koefisien regresi sebesar -0,030. Nilai sig 0,665 > alpha 0,05 menunjukkan bahwa variabel budaya clan (CLAN) tidak memiliki pengaruh yang signifikan terhadap corporate risk disclosure (CRD). Sehingga, hipotesis ketiga ( ) ditolak.

\section{Budaya Adhocracy dan Corporate Risk Disclosure}

Berdasarkan Tabel 4.15 dapat diketahui bahwa nilai sig variabel budaya adhocracy (ADHO) adalah sebesar 0,703 dengan nilai koefisien regresi sebesar 0,001. Nilai sig 0,703 > alpha 0,05 menunjukkan bahwa variabel budaya adhocracy (ADHO) tidak memiliki pengaruh yang signifikan terhadap corporate risk disclosure (CRD). Sehingga, hipotesis keempat ( ) ditolak.

\section{Budaya Market dan Corporate Risk Disclosure}

Berdasarkan Tabel 4.15 dapat diketahui bahwa nilai sig variabel budaya market (MRKT) adalah sebesar 0,371 dengan nilai koefisien regresi sebesar - 0,014. Nilai sig 0,371 > alpha 0,05 menunjukkan bahwa variabel budaya market (MRKT) tidak berpengaruh secara signifikan terhadap corporate risk disclosure (CRD). Sehingga, hipotesis kelima ( ) ditolak.

\section{Budaya Hierarchy dan Corporate Risk Disclosure}

Berdasarkan Tabel 4.15 dapat diketahui bahwa nilai sig variabel budaya hierarchy (HIRC) adalah sebesar 0,603 dengan nilai koefisien regresi sebesar - 0,010. Nilai sig 0,603 > alpha 0,05 menunjukkan bahwa variabel budaya hierarchy (HIRC) tidak berpengaruh secara signifikan terhadap corporate risk disclosure (CRD). Sehingga, hipotesis keenam ( ) ditolak.

Tabel 1.16 Uji t Malaysia

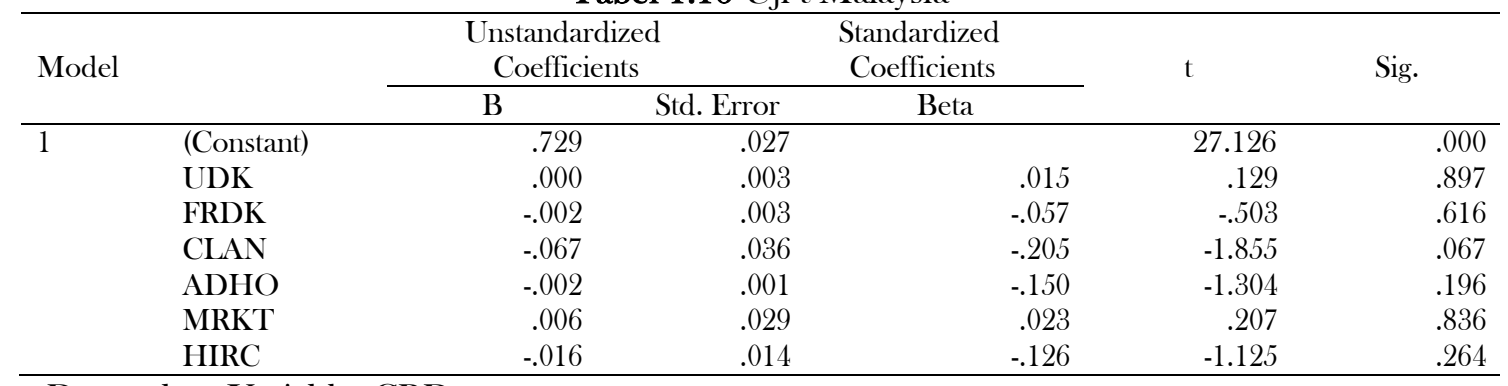

a Dependent Variable: CRD 


\section{Ukuran Dewan Komisaris dan Corporate Risk Disclosure}

Berdasarkan Tabel 4.16 dapat diketahui bahwa nilai sig variabel ukuran dewan komisaris (UDK) adalah sebesar 0,897 dengan nilai koefisien regresi sebesar 0,000. Nilai sig 0,897 > alpha 0,05 menunjukkan bahwa variabel ukuran dewan komisaris (UDK) tidak memiliki pengaruh yang signifikan terhadap corporate risk disclosure (CRD). Sehingga, hipotesis pertama ( ) ditolak.

\section{Frekuensi Rapat Dewan Komisaris dan Corporate Risk Disclosure}

Berdasarkan Tabel 4.16 dapat diketahui bahwa nilai sig variabel frekuensi rapat dewan komisaris (FRDK) adalah sebesar 0,616 dengan nilai koefisien regresi sebesar -0,002. Nilai sig 0,616 $>$ alpha 0,05 menunjukkan bahwa variabel frekuensi rapat dewan komisaris (FRDK) tidak memiliki pengaruh yang signifikan terhadap corporate risk disclosure (CRD). Sehingga, hipotesis kedua ( ) ditolak.

\section{Budaya Clan dan Corporate Risk Disclosure}

Berdasarkan Tabel 4.16 dapat diketahui bahwa nilai sig variabel budaya clan (CLAN) adalah sebesar 0,067 dengan nilai koefisien regresi sebesar -0,067. Nilai sig 0,067 > alpha 0,05 menunjukkan bahwa variabel budaya clan (CLAN) tidak memiliki pengaruh yang signifikan terhadap corporate risk disclosure (CRD). Sehingga, hipotesis ketiga ( ) ditolak.

\section{Budaya Adhocracy dan Corporate Risk Disclosure}

Berdasarkan Tabel 4.16 dapat diketahui bahwa nilai sig variabel budaya adhocracy (ADHO) adalah sebesar 0,196 dengan nilai koefisien regresi sebesar - 0,002. Nilai sig 0,196 > alpha 0,05 menunjukkan bahwa variabel budaya adhocracy (ADHO) tidak memiliki pengaruh yang signifikan terhadap corporate risk disclosure (CRD). Sehingga, hipotesis keempat ( ) ditolak.

\section{Budaya Market dan Corporate Risk Disclosure}

Berdasarkan Tabel 4.16 dapat diketahui bahwa nilai sig variabel budaya market (MRKT) adalah sebesar 0,836 dengan nilai koefisien regresi sebesar - 0,006. Nilai sig 0,836 > alpha 0,05 menunjukkan bahwa variabel budaya market (MRKT) tidak berpengaruh secara signifikan terhadap corporate risk disclosure (CRD). Sehingga, hipotesis kelima ( ) ditolak.

\section{Budaya Hierarchy dan Corporate Risk Disclosure}

Berdasarkan Tabel 4.15 dapat diketahui bahwa nilai sig variabel budaya hierarchy (HIRC) adalah sebesar 0,264 dengan nilai koefisien regresi sebesar -0,016. Nilai sig 0,264 > alpha 0,05 menunjukkan bahwa variabel budaya hierarchy (HIRC) tidak berpengaruh secara signifikan terhadap corporate risk disclosure (CRD). Sehingga, hipotesis keenam ( ) ditolak.

\section{KETERBATASAN PENELITIAN}

Penelitian ini tidak dapat terlepas dari beberapa keterbatasan. Keterbatasan tersebut pertama, periode pengamatan hanya satu tahun yaitu tahun 2016 sehingga hasil penelitian tidak dapat menggambarkan simpulan dalam jangka waktu tertentu. Kedua, dilihat dari nilai adjusted R Square khususnya di Indonesia hanya sebesar 0,057 atau 5,7\%, berarti masih banyak variabel-variabel lain yang dapat diteliti lebih lanjut yang diasumsikan dapat berpengaruh terhadap corporate risk disclosure. Ketiga, hanya menggunakan perusahaan manufaktur sehingga hasil penelitian ini tidak terlalu bisa menggambarkan pada tipe perusahaan lain. Keempat, penelitian ini hanya 
membandingkan dua negara yaitu Indonesia dan Malaysia dimana keduanya hampir memiliki karakteristik yang sama sehingga peneliti sulit menemukan perbedaan. Kelima, peneliti ini menggunakan indeks corporate risk disclosure yang dikembangkan oleh Uddin dan Hassan (2011) sehingga hasil yang berbeda dapat saja ditemukan ketika menggunakan indeks yang lain.

\section{KESIMPULAN}

Berdasarkan hasil analisis data dan pengujian hipotesis dengan menggunakan bantuan program SPSS Statistic 15.0, maka dapat ditarik kesimpulan ukuran dewan komisaris berpengaruh positif terhadap corporate risk disclosure di Indonesia. Ukuran dewan komisaris tidak berpengaruh terhadap corporate risk disclosure di Malaysia. Frekuensi rapat dewan komisaris tidak berpengaruh terhadap corporate risk disclosure di Indonesia. Frekuensi rapat dewan komisaris tidak berpengaruh terhadap corporate risk disclosure di Malaysia. Budaya clan tidak berpengaruh terhadap corporate risk disclosure di Indonesia. Budaya clan tidak berpengaruh terhadap corporate risk disclosure di Malaysia. Budaya adhocracy tidak berpengaruh terhadap corporate risk disclosure di Indonesia. Budaya adhocracy tidak berpengaruh terhadap corporate risk disclosure di Malaysia. Budaya market tidak berpengaruh terhadap corporate risk disclosure di Indonesia. Budaya market tidak berpengaruh terhadap corporate risk disclosure di Malaysia. Budaya hierarchy tidak berpengaruh terhadap corporate risk disclosure di Indonesia. Budaya hierarchy tidak berpengaruh terhadap corporate risk disclosure di Malaysia. Tidak terdapat perbedaan tingkat corporate risk disclosure di Indonesia dan Malaysia.

Saran yang dapat diberikan peneliti untuk penelitian selanjutnya menambahkan periode penelitian, supaya hasil penelitian dapat menggambarkan dalam rentang waktu yang lebih lama. Menambahkan variabel yang berpengaruh terhadap corporate risk disclosure seperti kepemilikan manajerial, kualitas audit dan jenis perusahaan. Memperluas obyek penelitian, ditambah dengan perusahaan sektor lainnya. Menambahkan negara pembanding yang memiliki karakteristik yang berbeda, contohnya Thailand dan Filipina. Menggunakan indeks corporate risk disclosure dari peneliti lain, misalnya Idroes (2011) sehingga dapat memperkaya hasil penelitian.

\section{DAFTAR PUSTAKA}

Abeysekera, I. (2010). The influence of board size on intellectual capital disclosure by Kenyan listed firms. Journal of Intellectual Capital, 11(4), 504-518.

Agustina, C. H., \& Ratmono, D. (2014). Pengaruh Kompetisi, Corporate Governance, Struktur Kepemilikan terhadap Pengungkapan Risiko (Doctoral dissertation, Fakultas Ekonomika dan Bisnis).

Amran, A., Manaf Rosli Bin, A., \& Che Haat Mohd Hassan, B. (2008). Risk reporting: An exploratory study on risk management disclosure in Malaysian annual reports. Managerial Auditing Journal, 24(1), 39-57

Atika (2016). Pengaruh Mekanisme Corporate Governance dan Budaya Perusahaan terhadap Corporate Risk Disclosure Serta Dampaknya Pada Firm Value dan Market Value (Studi Empiris pada Perusahaan Non-Keuangan yang Terdaftar di Bursa Efek Indonesia pada Tahun 2015). (Jurnal Akuntansi, Fakultas Ekonomi dan Bisnis Universitas Muhammadiyah Yogyakarta).

Aviolanda, S., \& Rohman, A. (2016). Pengaruh Ukuran Perusahaan, Ukuran Dewan Komisaris, Dewan Komisaris Independen, dan Struktur Kepemilikan terhadap Pengungkapan Risiko (Studi Empiris pada Perusahaan Manufaktur yang Terdaftar di Bursa Efek Indonesia Tahun 2012-2014) (Doctoral dissertation, Fakultas Ekonomika dan Bisnis).

Bank Indonesia, No. 14/14/PBI/2012, Transparansi dan Publikasi Laporan Bank. Bapepam LK, No. Kep-431/BL/2012, Penyampaian Laporan Tahunan Emiten atau Perusahaan Publik. 
ElKelish, W. W., \& Hassan, M. K. (2014). Organizational Culture and Corporate Risk Disclosures. International Journal of Commerce and Management, Vol. 24 (4), hal. 279-299.

Elzahar, H., \& Hussainey, K. (2012). Determinants of Narrative Risk Disclosures in UK Interim Reports. The Journal of Risk Finance, 13 (2), 133-147.

Fauzi, R. R. A. (2016). Pengaruh Corporate Governance dan Karakteristik Perusahaan terhadap Pengungkapan Risiko (Pada Perusahaan Property dan Real Estate yang Terdaftar di Bursa Efek Indonesia Periode 2010- 2014) (Bachelor's thesis, Jakarta: Fakultas Ekonomi dan Bisnis UIN Syarif Hidayatullah Jakarta).

Fiordelisi, F., \& Ricci, O. (2014). Corporate Culture and CEO Turnover. Journal of Corporate Finance, 28, 68-82.

Haniffa, R. M., \& Cooke, T. E. (2002). Culture, corporate governance and disclosure in Malaysian corporations. Abacus, 38(3), 317-349.

Hofstede, G. H. (1982). Culture's Consequences: International Differences in Work- related Values/cG. H. Hofstede. sage.

Ikatan Akuntan Indonesia. (2010). PSAK 60 (Revisi 2010): Instrumen Keuangan: Pengungkapan: Jakarta: IAI.

Nazaruddin, I., \& Basuki, A. T. (2016). Analisis Statistik dengan SPSS, Edisi Pertama, Danisa Media, Yogyakarta

OECD. (2015). G20/OECD Principles of Corporate Governance, OECD Publishing, Paris.

Prasista, D. F. (2013). Pengaruh Kepemilikan Manajerial, Political Visibility, Kinerja Keuangan, dan Board Gender terhadap Environmental Disclosure (Studi Empiris pada Perusahaan Manufaktur yang Terdaftar di Bursa Efek Indonesia dan Kuala Lumpur Stock Exchange Tahun 2015). (Jurnal Akuntansi, Fakultas Ekonomi dan Bisnis Universitas Muhammadiyah Yogyakarta).

Rasyidah, R. (2013). Perbandingan Corporate Governance dengan Sistem One-Tier Board di Inggris dan AS Terkait Efektififas Pencegahan Terjadinya Fraud dalam Korporasi. Global \& Policy Journal, $1,1$.

Saidah, S., \& Handayani, S. (2014). Pengaruh Mekanisme Corporate Governance terhadap Pengungkapan Risiko Perusahaan (Studi Empiris pada Laporan Tahunan Perusahaan Non Keuangan yang Terdaftar di BEI Periode 2011- 2013). Jurnal Akuntansi Unesa, 3(1).

Suhardjanto, D., Dewi, A., Rahmawati, E., \& M. Firazonia. (2012). Peran Corporate Governance dalam Praktik Risk Disclosures pada Perbankan Indonesia. Jurnal Akuntansi dan Auditing, $9(1) .16-30$.

Uddin, M. H., \& Hassan, M. K. (2011). Corporate Risk Information in Annual Reports and Stock Price Behavior in the United Arab Emirates. Academy of Accounting and Financial Studies Journal, 15 (1), 59-84.

Utomo, Y., \& Chariri, A. (2014). Determinan Pengungkapan Risiko pada Perusahaan Nonkeuangan di Indonesia (Doctoral dissertation, Fakultas Ekonomika dan Bisnis).

Yuniarti, I., \& Setyawati, E. (2016). Analisis Faktor-Faktor yang Mempengaruhi Pengungkapan Risiko Perusahaan (Studi Empiris Laporan Tahunan Perusahaan Non Keuangan yang Terdaftar di Bursa Efek Indoesia (BEI) Pada Tahun 2014) (Doctoral dissertation, Universitas Muhammadiyah Surakarta). 